Dominik Lewiński

ORCID: 0000-0003-2491-1071

Uniwersytet Wrocławski

https://doi.org/10.19195/1733-5779.38.17

\title{
Media a gospodarka. Systemowe uwarunkowania konsumpcjonizmu
}

Słowa kluczowe: media masowe, gospodarka, konsumpcjonizm, system społeczny, indywidualizacja

Keywords: mass media, economy, consumerism, social system, individualisation

Abstrakt: Artykuł podejmuje próbę wyjaśnienia zjawiska medializacji gospodarki w perspektywie systemowo-konstruktywistycznej, rekonstruuje warunki koewolucji systemowej oraz genezę nowoczesnego konsumpcjonizmu. Proces dyskursywizacji gospodarki zostaje odniesiony do problematyki uzyskania kompatybilności ze środowiskiem. Końcowym wnioskiem jest teza, że tożsamość nowoczesnej, zindywidulizowanej jednostki ukonstytuowana została w efekcie sprzężeń międzysystemowych.

\section{Media and the economy. Systemic conditions of consumerism}

\begin{abstract}
The article attempts to explain the phenomenon of medialization of the economy in the system-constructivist perspective by reconstructing the conditions of systemic co-evolution and the genesis of modern consumerism. The author claims that the process of the discursive economy construction is related to achieving compatibility with its environment. The final conclusion of the paper is that the identity of the modern, individualized person was constituted as a result of a whole series of inter-system couplings.
\end{abstract}

Przedstawione rozważania utrzymane są w teoretycznej optyce tak zwanego operacyjnego konstruktywizmu Niklasa Luhmanna, teorii hermetycznej i niepoddającej się łatwemu streszczeniu — dlatego też rozpocznę od skrótowego przedstawienia jej głównych założeń relewantnych ze względu na tematykę artykułu, dalej zdając się na formę eseju, która (mam nadzieję) ułatwi odbiór przez kontekstualizację abstrakcyjnych, luhmannowskich pojęć. Luhmann wychodzi z założenia, że komunikacja jest autonomicznym, zamkniętym i autopojetycznym systemem. System społeczny nie składa się z ludzi, lecz z międzyludzkich powiązań komu- 
nikacyjnych, system społeczny (,społeczeństwo”) konstytuowany jest przez procesy komunikacyjne, jest on całokształtem wzajemnie dostępnych, komunikacyjnie osiągalnych przeżyć i działań. Komunikacja splata społeczeństwo w jedność (Willke: „członkowie systemu społecznego jako osoby należą do środowiska systemu” i ,systemy społeczne nie składają się ze zbiorowiska ludzi, lecz z procedowania komunikacji”) 1 . Komunikacja nie jest rezultatem ludzkiej działalności, ale produktem systemu społecznego, jednostki ludzkie nie mogą komunikować, tylko komunikacja może komunikować. Systemy psychiczne (jednostki ludzkie) operują znaczeniem w zamkniętych kontekstach świadomości. Systemy komunikacyjne operują znaczeniem w zamkniętych kontekstach komunikacyjnych. Systemy psychiczne opracowują sens w formie myśli i wyobrażeń, systemy społeczne zaś opracowują sens w formie symbolicznie zapośredniczonych komunikacji, niezbywalnych dla ich (systemów) ciągłości. Komunikacja i świadomość są strukturalnie sprzężone, ale są różnymi systemami, będącymi dla siebie wzajem środowiskiem. Systemy tworzą się i samodzielnie odtwarzają, przetwarzając kompleksowość przez środki komunikacji w nieustannym procesie selekcji ${ }^{2}$. Komunikacja nie jest rozumiana jako językowy proces interakcji podmiotów, lecz jako bezpodmiotowe zdarzenie, jako ciągły proces selekcji ogółu dostępnych potencjalnych wydarzeń. Systemy społeczne to autopojetyczne systemy komunikowania. Podstawowymi problemami systemów są redukcja złożoności powiązana z kontyngencją oraz selekcja. Aby system mógł się odtwarzać, musi ograniczać relacje między sobą a środowiskiem, jest zmuszony do ciągłych selekcji istotnych relacji z otoczeniem, musi nieustannie przetwarzać granicę system/środowisko - a jeśli systemy społeczne nie składają się z ludzi, to granicę systemu stanowi komunikacyjnie osiągalny sens. Sens zawiera selektywne odniesienie między systemem a środowiskiem, odgranicza systemowo specyficznie to, co intersubiektywnie ma uchodzić za sensowne, od tego, co bezsensowne. Sens należy postrzegać jako formę porządkującą świat i działanie społeczne wyznaczające granice systemu. Wspólna sensowna orientacja działania, którą cechuje możliwość wzajemnego zrozumienia, jest podstawowym warunkiem interakcji społecznych ${ }^{3}$. Oczywiście sensu nie konstytuują ludzie - sens to medium służące organizacji różnic. Systemy społeczne (komunikacyjne) powstają w wyniku doświadczenia podwójnej kontyngencji, albowiem systemy (także ludzie) pozostają dla siebie „czarnymi skrzynkami”, to znaczy obserwują jedynie regularności w swoich zachowaniach, a jednocześnie przyjmują, że te regularności są rezultatem nieobserwowalnych, wewnątrzsystemowych związków przyczynowych i muszą orientować się wzajem, ukierunkowując selekcję własnych stanów, uwzględniając fakt, że inne, relewantne systemy

${ }^{1}$ H. Willke, Systemtheorie I: Grundlagen, Stuttgart 1996, cyt. za: M. Fleischer, Teoria kultury $i$ komunikacji, Wrocław 2002, s. 166-180.

2 N. Luhmann, Die Wissenschaft der Gesellschaft, Frankfurt am Main 1990, s. 31.

${ }^{3}$ H. Retter, Komunikacja codzienna w pedagogice, Gdańsk 2005, s. 176. 
też są kontyngentne, to znaczy mogą być takie, ale również inne, może zdarzyć się coś, ale też coś innego. Niemożność determinowania owej sytuacji nadaje każdej aktywności strukturujące znaczenie, produkując autopoietyczną komunikację, według zasady ,ja pozwolę się zdeterminować tobą, jeśli ty dasz się zdeterminować mną". Po tych uwagach łatwiej będzie zrozumieć specyficzną, Luhmannowską definicję komunikacji jako autonomicznego, samoreferencyjnego generowania selekcji, ,komunikacja to proces, który na selekcje reaguje selekcyjnie, to znaczy wzmacnia selektywność". Komunikacja jest syntezą trzech rodzajów selekcji: 1. informacji, która selekcjonuje spośród różnych stanów rzeczy; 2. przekazu, który selekcjonuje spośród różnych możliwości zachowań; 3. rozumienia, oczekiwania, że w wyniku selekcji komunikacja zostanie przyjęta. ,„Jakkolwiek zawartość komunikacji musi być inna, niż mogłaby być. Ktokolwiek musi się zdecydować przekazać ją, mimo że mógłby także tego zaniechać. I ktokolwiek musi to, co się stało, zrozumieć, chociaż mógłby równie dobrze zajmować się innymi rzeczami albo przeoczyć dyferencje i selekcje, albo nie osiągnąć ich".

Jeśli wziąć pod uwagę podwójną kontyngencję, to selekcje są ofertami, by dokonać recepcji bądź odrzucić komunikację, by wyrazić zgodę (lub jej nie wyrażać) na jej merytoryczną wymowę, by w rozumieniu potwierdzić sens lub zakwestionować go. W tej perspektywie udana komunikacja staje się zjawiskiem praktycznie nieprawdopodobnym. Po pierwsze, nieprawdopodobne jest to, by ktoś w ogóle rozumiał to, co myśli ktoś inny, z uwagi na istniejące rozdział i indywidualizację świadomości. Po drugie, nieprawdopodobne jest, by komunikacja dotarła do kogoś więcej niż tylko do osób obecnych w konkretnej sytuacji, wynika to z czasowej i przestrzennej ekstensji. Po trzecie, nieprawdopodobny jest sam sukces komunikacji, przejęcie przez odbiorcę treści komunikacji jako przesłanki własnego zachowania $^{4}$. Uprawdopodobnianie komunikacji jest osiągane przez — jak to Luhmann nazywa — „ewolucyjne zdobycze”, czyli media komunikacji, których wyróżnia trzy rodzaje. Po pierwsze, język jako medium, które w sposób sensowny używa znaków, daleko wykracza poza ramy zwykłego postrzegania i otwiera nieskończenie wiele możliwości komunikowania polegającego na przedstawianiu wydarzeń $\mathrm{w}$ formie informacji lub grupowaniu informacji $\mathrm{w}$ formie tematów.

Po drugie, media przetwarzające (pismo, druk, radio, internet itp.), które intensyfikują i rozszerzają sposobności komunikacyjne, ułatwiają standaryzację. Po trzecie, najważniejsze dla funkcjonalnego zróżnicowania współczesnych społeczeństw, tak zwane symbolicznie zgeneralizowane media komunikacji (Parsons). Symbolicznie zgeneralizowane media czynią komunikację możliwą, ustalają reguły możliwych kombinacji symboli ${ }^{5}$, selekcjonują możliwe tematy, umożliwiają społeczne interakcje. Funkcją mediów jest transmisja skutków selekcji. W nowoczesnym społeczeństwie funkcyjnym takimi mediami są między innymi pieniądz,

\footnotetext{
${ }^{4}$ N. Luhmann, Social Systems, Stanford 1995, s. 157-160.

5 N. Luhmann, Die Gesellschaft der Gesellschaft, t. 2, Frankfurt am Main 1998, s. 382.
} 
władza, wiara, prawda, miłość. Polityka posługuje się władzą, gospodarka pieniądzem, nauka prawdą, religia wiarą i tak dalej. Granice zgeneralizowanych mediów to granice subsystemów, nowoczesne społeczeństwo właśnie dzięki nim funkcjonuje. Zgeneralizowane media stanowią motywację, wprawiają w ruch komunikacje i są wyrazem mechanizmów sterujących kultury, nie tylko samodzielnie się reprodukując, lecz także tworząc kody (na przykład binarne), wzory interpretacyjne i konstrukcyjne dla tematów komunikacji.

\section{Wprowadzenie}

Sprzężenie systemu mediów masowych z systemem gospodarki uważam za najważniejszy proces komunikacyjny definiujący dynamikę późnej nowoczesności. Systemy zdają się na siebie, dostarczając wzajem rozwiązań pozwalających utrzymać środowiskową kompatybilność. Już nie tylko szybkość giełdy, podejmowanie decyzji gospodarczych, formy transakcji i tym podobne zawieszone zostają strukturalnie na mediatyzowanych rusztowaniach. Już nie tylko referencje medialne schodzą się z gospodarczymi w symbiotycznym mechanizmie reklamy, który połączył uwagę i pieniądz. Medializacja gospodarki sama w sobie wytwarza specyficzne semantyczne korelaty środowiskowe, które dla samych mediów czy gospodarki byłyby zapewne nieosiągalne. Mam na myśli aktora-sieć, którego łącza transstrukturalne obejmują indywidualność systemów psychicznych, style życia, branding, konsumpcjonizm, kulturę popularną, ciała i rzeczy, design i gust, tożsamość i osobowość.

Dyskusja nad medializacją gospodarki, o ile w ogóle miałaby się rozpocząć, powinna przewietrzyć normatywne mgły ciągle zalegające nad procesami zbiorczo obserwowanymi jako „konsumpcjonizm”. Wymagałoby to jednak nie tylko znaczących rewizji w planie teoretycznym — być może przestawienia opisywania funkcji i wkładów medium pieniądza $z$ torów marksowskich na simmlowskie ${ }^{6}$ lecz także rezygnacji z utrwalonych form obserwowania opartych na przywilejach akademickiej dystynkcji, skłaniających do krytycznomedialnej protekcjonalności ${ }^{7}$. Najgłośniejsze dotychczasowe osiągnięcia w tym względzie: szkoły frankfurckiej, Benjamina Barbera, Rogera Scrutona, Zygmunta Baumana, Jeana Baudrillarda, a nawet Jürgena Habermasa mogą oddziaływać zniechęcająco. Nie jest jednak żadnym teoretycznie satysfakcjonującym rozwiązaniem poprzestanie na diagnozie medialno-gospodarczego ogłupienia świata. Dyskusja, którą mam na myśli, przestawiłaby kierunek pytań na warunkowanie strukturalne. Jak i dlaczego dzieje się konsumpcjonizm? Jakie struktury uczyniły go możliwym i jakie

${ }^{6}$ G. Simmel, Filozofia pieniadza, przeł. A. Przyłębski, Warszawa 2012.

7 Zob. wyczerpująco na temat tej ,dyspozycji scholastycznej” P. Bourdieu, Medytacje pascaliańskie, przeł. K. Wakar, Warszawa 2006, s. 23-117. 
złożenia strukturalne podtrzymują tę specyficzną formę autopoiesis? Jak i dlaczego stała się możliwa medializacja gospodarki?

Oczywiście system gospodarki wykazuje własne specyfikacje strukturalne i ewolucyjne, historycznie oparte na postępującej autonomizacji gospodarki, wyróżnicowywaniu się typowo gospodarczych form komunikacji i wiązaniu ich w samoreferencyjny system. Nie ma szczególnej potrzeby w tym miejscu przywoływać niuanse autokonstytucji gospodarki, choć należałoby wspomnieć o wynalezieniu i przepracowaniu własności ${ }^{8}$, jednoczącym wpływie medium pieniądza czy preferencjach w kierunku samoorganizacji w postaci przedsiębiorstw, oddzieleniu produkcji od konsumpcji oraz czasu wolnego od czasu pracy i tak dalej.

Zacząć należałoby od pytania o zmianę preferencji samoopisu społeczeństwa. Od pewnego czasu zaobserwować można odejście od opisywania społeczeństwa jako kapitalistycznego czy przemysłowego (co samo w sobie było jedynie indykatorem dynamiki systemu gospodarki) w kierunku opisów akcentujących aspekty komunikacji masowej: społeczeństwo sieciowe, informacyjne, medialne, refleksyjne. Równocześnie mówi się o przeniesieniu punktu ciężkości w gospodarce z produkcji na konsumpcję, o społeczeństwie konsumpcyjnym. Niewiele jednak wskazywałoby na osłabienie relewancji procesów gospodarczych, wycofywaniu się struktur opartych na pośrednictwie pieniądza, poluźnieniu sprzężeń gospodarki z systemami w środowisku, odwrotu od komodyfikacji. Zakładać raczej powinniśmy, że zmiana perspektywy obserwowania, poza niewątpliwym wpływem koniunktur intelektualnych, ma swe źródło w porażce opisu uplasowania współczesnego systemu gospodarki w systemie społeczeństwa, porażce, która wynika z teoretycznych niedoborów. Nie oznacza to oczywiście, iż przekierunkowanie opisów jest jakoś zasadniczo błędne, jest jedynie jednostronne: nowa dynamika gospodarki, widoczna w opisach konsumpcjonizmu, jest powiązana symbiotycznie z medializacją, refleksyjnością, informacyjnością itp.

\section{Gospodarka a selekcja}

Skrótowo rzecz ujmując, system gospodarki stanął w obliczu zmultiplikowanego na wielu poziomach problemu selekcji: regulacji selektywności z własnym wewnętrznym środowiskiem — rynkiem, regulacji selektywności w sytuacji czasowego upłynnienia, sektorowych, samoreferencyjnych reorientacji przyszłościowych (inwestowanie, giełdy itp.), wreszcie selektywności typowo środowiskowych, z koniecznością dostarczenia motywacji selekcyjnych na zewnątrz systemu na przykład w formie zaopatrzenia organizacji gospodarczych w pracowniczy input oraz konsumencki output, selektywności decyzji producenckich. W tradycyjnym ujęciu selektywność nie jest problemem, wszelkie przesłanki uzasadniające gospodarcze decyzje rozstrzygane są przez samą autopoiesis gospodarki (na

${ }^{8}$ Zob. M. Kaczmarczyk, Wstęp do socjologicznej teorii własności, Warszawa 2006. 
przykład w postaci mechanizmu popyt-podaż), a kompatybilność środowiskową zapewnia hydraulika potrzeb. Ale uzasadnienia oparte na założeniach o zaspokajaniu potrzeb i autoregulacji przez popyt/podaż tracą z czasem swą początkową skuteczność - gdyby system gospodarczy kontynuował na owych założeniach własną autoreprodukcję, ustabilizowałby swoją dynamikę na poziomie całkowicie uzależnionym od irytacji przez środowisko. Czekano by na popyt i zaspokajano go, punkt-w-punkt. Korzyści z przejrzystości, wystarczające zapewne społeczeństwom segmentacyjnym, nie są jednak w stanie zrekompensować otwarcia strukturalnego warunkowanego anonimowością i potencjałem wolnościowym pieniądza. Pieniądz motywuje sam w sobie i dostarcza kontyngencji - na przykład sytuację, w której każdy może kupić, co chce. Już sama ta możliwość wytwarza niestabilność i nieprzejrzystość. Sytuacja gospodarki nasyconej potęguje kontyngencję i wytwarza presję na koordynację selekcji.

Przede wszystkim mechanika pieniądza nie jest już w stanie obsłużyć kompatybilności gospodarki ze środowiskiem. Można wybierać produkty i usługi droższe, a nie tańsze. Dopóki środowisko było obserwowane w ramach konstrukcji dyktowanych rozkładem dystynkcji (z typową regulacją: konsumencka konieczność w odniesieniu do klas niższych; ostentacyjna niekonieczność w odniesieniu do klas wyższych ${ }^{9}$ ) problem ów nie tworzył większego zagrożenia reprodukcji gospodarki. Również rozwój mody, polegającej początkowo na naśladowaniu klas wyższych przez niższe, nie powodował szczególnych perturbacji. Choć już wówczas było widoczne, że kodowanie zysk/strata projektowane przez gospodarkę na zachowania i działania środowiska ma swoje ograniczenia. Gdy załamuje się warstwowy model komunikacji społecznej, a gospodarka wkracza w stan nasycenia, możliwości autoregulacji i obserwacji metodą homo oeconomicus zawodzą. Na przykład cena nie jest w stanie skutecznie skoordynować konsumpcji. Przestaje być faktorem bezpośredniego wyboru, a staje się jedynie wskaźnikiem orientującym w przestrzeni segmentów rynkowych. Nawet w obszarze segmentów low-end. Cena nie mówi już, co mam kupić, wskazuje tylko, wśród czego mogę wybierać. A możliwość „racjonalnego” wyboru zostaje częstokroć sparaliżowana przez segmentacyjną homogenizację jakościową.

Ale wybory muszą być dokonywane, zarówno po stronie systemu, jak i środowiska - potrzebują więc struktur. Po stronie systemu gospodarki strukturyzacja wymaga specyficznej przebudowy czasu - skoordynowanej orientacji na przyszłość. Początkowo wyzwalaczem przyszłości jest sam kredyt ${ }^{10}$. Czas przyszły staje się wycenialnym zasobem, także ryzyko powiązane z czasową kontyngencją daje się kalkulować w medium pieniądza. Ale dopiero rosnąca nadmiarowość gospodarki w formie konkurencji sprawia, że środowisko staje się nieprzejrzyste — nie jest już na przykład pewne, czy konsumenci znów zdecydują się na

9 Zob. T. Veblen, Teoria klasy próżniaczej, przeł. J. i K. Zagórscy, Warszawa 2008.

10 J. Vogl, Widmo kapitału, przeł. K. Sosnowska, Warszawa 2015, s. 71. 
nasz produkt, czy skorzystają z oferty konkurencji. Dochodzi do tego stabilizacja niestabilności cen. Oparcie na przeszłości i teraźniejszości nie jest już możliwe, kalkulacje muszą uwzględniać przyszłość. Tylko niepewność przyszłości jest pewna. Pojawia się przymus rozwoju, widoczny na przykład w forsowaniu nowości. Teraz widać już wyraźnie, iż kalkulacje oparte na prekonstruowanej retoryce potrzeb zawodzą. Gospodarka musi wymyślać potrzeby, aby następnie je zaspokajać. Ale czy w takim razie w ogóle można jeszcze mówić o potrzebach? Któż i w jaki sposób mógłby odczuwać potrzebę produktu, którego jeszcze nie ma? Retoryka potrzeb jest teoretycznie niebezpieczna także o tyle, że prowokuje do następującej konstrukcji: nowo wymyślane potrzeby muszą uzyskać rezonans w środowisku, w tym celu używa się reklamy, która wperswadowuje odpowiednie potrzeby i potrzeby potrzeb w systemy psychiczne. Reklamowa hipnoza produkuje konsumpcjonizm. Nie widać jednak powodu, dla którego środowisko miałoby w ogóle reagować na reklamowe irytacje. Gospodarka może wywierać presję w celu sprzedaży, ale dlaczego systemy psychiczne miałyby odpowiadać autopresją w kierunku kupna? Czy nie za łatwo i zbyt mechanicznie zakłada się kompatybilność, która musi być dopiero osiągnięta? Metaforyka potrzeb wyczerpuje się dziś na naszych oczach w formie badań rynku, których celem jest rozeznanie, czy nowe produkty lub usługi mogą liczyć na relewancję ze względu na potrzeby, czy — innymi słowy — mają szanse rynkowego powodzenia. Nie ulega wątpliwości, że badania rynkowe tego rodzaju mają charakter w dużej mierze legitymizacyjny i uzasadnieniowy i że służą jako wewnątrzsystemowy mechanizm decyzyjny, nie zaś realnościowe sprawozdanie ze stanu środowiska. Gdyby było inaczej, produkty i usługi, które pomyślnie przeszłyby pretesty, ze względu na potrzeby miałyby niejako zagwarantowane powodzenie, te zaś, których pretest wypadłby niepomyślnie, nie miałyby szans w rynkowej grze. Nic takiego jednak się nie dzieje. Produkty, którym badania nie wróżyły sukcesów, osiągają sukcesy (na przykład Sony Walkman, Absolut Vodka w USA). Stopień niepowodzenia nowych produktów czy usług, którym badania zapowiadały powodzenie, osiąga, wedle różnych szacunków, kilkadziesiąt procent (do nawet 80\%). Staje się to oczywiste, jeśli weźmiemy pod uwagę samą kontyngencję jako taką. Co skłania przedstawicieli branży brandingowej do melancholijnych twierdzeń w rodzaju: „konsument nie zachowuje się tak, jak mówi, nie mówi tego, co myśli, i nie myśli tego, co czuje" "11. Gdyby rynkowe pretesty relewancji ze względu na potrzeby osiągały to, co obiecują, mielibyśmy do czynienia z quasi-deterministycznym porządkiem nieustannego gospodarczego sukcesu, przewidywalnie zakłócanego jedynie perturbacjami wnoszonymi przez konkurencję, kalkulowalnymi w ramach konstrukcji homo oeconomicus. Ale przecież tak się nie dzieje. Linia strukturalna oferowana przez metaforykę potrzeb jest po prostu nietrafnie poprowadzona, wyznacza ona bowiem trajektorię prostej łączności między gospodarką a naturą ludzką, wyraża-

11 D. Ogilvy, Wyznania czlowieka reklamy, przeł. W. Madej, Warszawa 2000, s. 13. 
ną choćby przez tak zwaną piramidę Maslowa. Inaczej mówiąc: opisy gospodarki, stylizujące ją na rodzaj Wielkiej Wszetecznicy, która bezpośrednio oddziałuje na systemy psychiczne dzięki hydraulice potrzeb ,prawdziwych” i ,sztucznych”, wdrukowywaniu w psychiki niepotrzebnych potrzeb, nie daje się obronić, ani empirycznie, ani teoretycznie. Zastanawiające zapewne w przywołanym kontekście jest także to, że humanistyczne antykonsumpcjonistyczne jeremiady opierające się na koncepcie tyranii wymyślonych potrzeb, odnoszą się do systemów psychicznych z dość dobrze widoczną dawką pogardy — z ograniczonym zaufaniem do autonomii człowieka. Ale w paradygmacie krytycznym nie widać innego sposobu na połączenie gospodarki z konsumpcjonizmem czy wyjaśnienie samego konsumpcjonizmu niż obserwacja sprzężenia za pomocą logiki potrzeb. Dodajmy jeszcze, że retoryka potrzeb rozumiana jako hipoteza wyjaśniająca mechanizmy rynkowe jest niefalsyfikowalna i oferuje zamiast wyjaśnienia tylko jego pozory. Jeśli jakiś produkt czy jakaś usługa osiągają rynkowe powodzenie, najwyraźniej zaistniała w tym względzie potrzeba, jeśli zaś dany produkt czy dana usługa powodzenia nie osiągają - to zakłada się, iż stosownej potrzeby nie było. Takim teoretycznym wybiegiem można obsłużyć praktycznie dowolną rynkową sytuację, niczego przy okazji nie wyjaśniając. Retoryka potrzeb to jedynie konstrukcja uzasadnieniowa. Przynależy ona do szerszego repertuaru uzasadnień obsługujących opis gospodarki okresu przejściowego, razem z ceną, jakością i gustem.

Repertuar ów cieszy się o tyle jeszcze powodzeniem, że jest chętnie przywoływany przez konsumentów dla uzasadnienia decyzji i ujawnienia motywacji podejmowanych w procesie konsumpcji. Ale gdyby uzasadnienia ceną, jakością, gustem i potrzebą lub ich dowolną kombinatoryką miały odzwierciedlać konfiguracje struktur zaangażowanych w reprodukcję konsumpcji, to mielibyśmy do czynienia z paraliżem konsumpcji. Stosunek cena-jakość nie dostarcza wystarczających przesłanek selekcyjnych. Odwołanie się do mitologii gustu i retoryki potrzeb mogłoby ostatecznie uchodzić za rozstrzygający faktor selekcji, jednakże pozostawia niewyjaśnioną koordynację selekcji. Jeśli bowiem — a tak się najczęściej dziś zakłada - gust i potrzeba są zindywidualizowanym stanem systemu psychicznego, to wyjaśnić należy, jak dochodzi do masowych koordynacji i dyskoordynacji ofert konsumpcyjnych z decyzjami konsumenckimi. Nie mamy przecież do czynienia z mechanizmem chybił trafił, przypadkowymi zestrojeniami stanów psychicznych z właściwościami ofert. Gdyby własny gust był własny, to koordynacje byłyby zbyt nieprawdopodobne do osiągnięcia. Jakie agregacje własnych gustów i potrzeb prowadziłyby na przykład do zakupu perfum Poison (Dior) w stopniu umożliwiającym marce rynkową relewancję? Prędzej czy później musi pojawić się pytanie o komunikacyjną strukturację gustu i jego pochodzenie. Nie można dzisiaj poprzestać na odpowiedzi na to pytanie sformułowanej w ramach siatki pojęciowej opartej na klasowych rozróżnieniach, jak to swego czasu uczynił Pierre Bourdieu ${ }^{12}$.

12 P. Bourdieu, Dystynkcja. Społeczna krytyka władzy sądzenia, przeł. P. Biłos, Warszawa 2006. 
Najwyraźniej struktury, na których opierają się procesy selekcji, mają charakter mniej lub bardziej latentny, uzasadnieniowe opisy zaś mają właśnie ową latencję podtrzymywać i maskować zarazem. I chodzi tu o latencję zarówno świadomości, jak i komunikacji ${ }^{13}$.

\section{Problem latencji}

Na poziomie świadomości latencja sprzężeń strukturalnych opiera się przeważnie właśnie na kombinatoryce cena/jakość lub specyfikacji funkcjonalnej produktu/usługi; komunikacja dopuszcza tutaj bardzo różnorodne i wyczerpujące semantyki. W odwodzie pozostają ewentualnie uzasadnienia odwołujące się do kodów estetycznych, choć te miewają już swoje ograniczenia i rozkłady, na przykład estetykę „męską” i ,kobiecą”. Innymi słowy ludzie kupują coś, ponieważ kierują się, jak twierdzą, potrzebami, wyceną jakościowo-cenową lub cechami funkcjonalnymi (,,bezpieczny samochód”, „wydajny krem”, „,smaczny ser”, „,wygodne buty”), wspomagają się estetyką (,ładny samochód”, ,piękna bluzka”), w ostateczności zaś przywołują moment samoreferencji świadomości (,,podoba mi się”, „w moim guście”, „pasuje mi”). Rozwinięcie refleksji jest jednak przeważnie blokowane przez latencję komunikacji: brakuje rozpowszechnionych struktur komunikacyj-

13 W teorii Luhmanna problematykę latencji ujmuje się następująco: „Rozróżniać trzeba latencję świadomości oraz latencję komunikacyjną. Świadomość należy do (interpenetrującego) środowiska systemów społecznych, latencja świadomości (nieświadomość, niewiedza) jest zatem w pierwszej mierze jedynie środowiskową przesłanką budowy systemów społecznych. Wszystkowiedzące systemy psychiczne pozostawałyby wobec siebie w relacjach pełnej przezroczystości, a więc nie mogłyby tworzyć systemów społecznych. Trzeba od tego odróżnić latencję komunikacyjną w sensie braku określonych tematów umożliwiających komunikację i nią sterujących. [...] W odniesieniu do obu rodzajów latencji rozróżnić trzeba przynajmniej trzy poziomy umiejscowienia problemu. Istnieje (1) latencja czysto faktyczna w sensie niewiedzy lub niebrania czegoś pod uwagę przy wyborze tematów procesu komunikacyjnego; ponadto (2) latencja faktyczna opierająca się na niemożliwości wiedzy, względnie komunikacji; istnieje również (3) latencja strukturalno-funkcjonalna, a mianowicie latencja pełniąca funkcję ochrony struktury [właśnie ten ostatni rodzaj latencji jest uwzględniany w moim artykule — D.L.]. [...] Jeśli struktury wymagają ochrony w postaci latencji, to nie oznacza to, że świadomość, względnie komunikacja, nie jest możliwa, a jedynie, iż świadomość lub komunikacja zniszczyłaby struktury, względnie spowodowałaby znaczne restrukturyzacje oraz że ta perspektywa nabiera charakteru latencji, czyli blokuje świadomość lub komunikację. Przy analizie tego ostatniego przypadku latencji nie da się w szczególności uniknąć orientacji na różnicę między latencją świadomościową a komunikacyjną, wszak jest to ta różnica, która nadaje latencji strukturalno-funkcjonalnej, tak w systemach społecznych, jak i w psychicznych, jej niepewny charakter. Świadomość może podminowywać latencje społeczne, dążąc do komunikacji; z drugiej strony komunikacja może sabotować latencje psychiczne, szczególnie w formie komunikacji o komunikowaniu tego, kto definiowany jest jako ktoś, kto stara się chronić i ukrywać swe latencje. Systemy psychiczne, względnie społeczne, zagrażają sobie wzajemnie już przez to, że ich zapotrzebowania na latencję nie są ze sobą zgodne, a procesy operacyjne nie są identyczne”, N. Luhmann, Systemy społeczne. Zarys ogólnej teorii, przeł. M. Kaczmarczyk, Kraków 2007, s. $315-317$. 
nych dla wyższych poziomów opisu. O gustach się przecież nie dyskutuje. A jeśli już, to w sposób omijający obserwację wyższego rzędu, obserwację obserwacji. Ktoś kupuje białe kozaczki, bo uważa je za „ładne”, choćby dlatego, że są „kobiece” - ale obserwacja obserwacji „kobiecości” nie jest już dokonywana. Ktoś kupuje perfumy Poison i wystarczającym uzasadnieniem jest fakt, że „podoba się zapach”, można jeszcze wyjaśnić, iż to z powodu jego „zmysłowości” — ale operowanie różnicą zmysłowe/niezmysłowe pozostaje niewyjaśnialne ani w aspekcie aktywacji różnicy, ani w aspekcie przyczyn atrybucji różnicy. Konsumpcja jest indywidualizowana i spychana w otchłań latencji świadomości. Obserwacje odwołujące się do struktur społecznych są nierzadko atrybuowane (to inni kupują na przykład „,z powodu reklamy”) i ostatecznie przeważnie kończą w stanach świadomości Innego. Lecz tak, jak nie wolno uświadamiać nam sobie, że małżeństwa nie są zawierane z miłości, tak nie wolno uświadamiać nam sobie za dobrze, dlaczego coś jest kupowane.

Ale dlaczego komunikacja jest hamowana? Jakie struktury i dlaczego są chronione przed zniszczeniem lub znaczącą restrukturyzacją przez rozpowszechnioną latencję, która, niczym parasol ochronny, rozpościera się nad „konsumpcjonizmem"? Nie jest przecież tak, że komunikacja jest tutaj jakoś zasadniczo niemożliwa z przyczyn kompetencyjnych, dostępu do zasobów komunikacyjnych itp. Każdy już wie, że należy do „grupy docelowej”, że jest obiektem marketingu z jego osławionymi „technikami” i ,trikami”. Że są tacy, którzy „utożsamiają się" $\mathrm{z}$ bohaterami reklam i dlatego kupują itp. Ujawnianie zakładanej mechaniki konsumpcjonizmu nie narusza struktur ani — tym bardziej — nie zmniejsza pokładów latencji. Wiemy, że konsumpcja zachodzi w wyniku specyficznych oddziaływań, co nie przeszkadza uważać, że nie jest nimi skrępowana lub że zachodzi przypadkowa, udana koincydencja. Wybieramy w świadomości ułudy wyboru. Hipokryzja ${ }^{14}$, która wychodzi na jaw, hipokryzja w pełnym świetle komunikacji i świadomości, pozostawiająca relewantne komunikacje niezmienionymi, jest właśnie specyficznie współczesną formą obchodzenia się z latencją. Nie może to dziwić, wszak rezygnacja z uniwersalnych roszczeń w postaci semantyk tradycji czy Natury na rzecz rozbudowy autorefleksji nierzadko zmierzającej do zaawansowanej autopodejrzliwości sprawia, że dopiero struktury, które uwzględnia-

${ }^{14}$ Pojęcie hipokryzji nie ma tu charakteru wartościującego i nie odnosi się do intencji czy w ogóle stanów świadomości — obejmuje ono zbiorczo te sytuacje komunikacyjne, w których dochodzi do ujawnienia podejrzenia różnicy między świadomym a nieświadomym (w socjologii znanej jako różnica między funkcją jawną a ukrytą, względnie między programem jawnym a ukrytym), na przykład ktoś na poziomie świadomości kocha, lecz sugeruje się, że na poziomie nieświadomym spełnia jedynie przymusy samolubnego genu lub ulega kombinacji czynników chemicznych/hormonalnych; ktoś kupuje ze świadomością, że kieruje się kryterium ceny i jakości, lecz sugeruje się, że w rzeczywistości uległ reklamowym perswazjom — w obu przypadkach sugeruje się, że osoba myśli coś innego, niż w rzeczywistości robi, i ukrywa to przed samą sobą. 
ją podejrzenia, mogą przyczyniać się do ukrycia, ochrony innych struktur przed ujawnieniem ich funkcji. Na przykład rozpanoszona w mediach socjobiologia dostarcza obfitości redukcjonistycznych podejrzeń odnoszących się do miłości, głoszących, że jest ona procesem w głównej mierze „chemicznym”, że poddana jest logice samolubnych genów, że jest niezależna od woli zaangażowanych podmiotów; podejrzeniu uczyniono zadość, miłosna hipokryzja została ujawniona, co w żaden sposób nie przeszkadza autoreprodukcji kodów miłosnych, nie narusza semantyk i struktur, bo ukryte zostało co in neg o. Podobnie dzieje się w wypadku konsumpcjonizmu: odpowiednia porcja ujawnień, realizacja podejrzeń umożliwia funkcjonalną latencję i autoreprodukcję konsumpcjonizmu. I tak jak mass medialne rozpowszechnienie wiedzy socjobiologicznej nie zmienia charakteru miłości, tak massmedialna dyspersja „chwytów marketingowo-reklamowych” nie restrukturyzuje konsumpcji. Być może dzieje się tak za sprawą szczególnej stylizacji ujawnień, zmierzającej przeważnie ku narracjom deterministycznym i quasi-deterministycznym, które utrudniają reakcję strukturami. Cóż bowiem można poradzić na to, że zakochujemy się z powodu szczególnej kombinacji aktywności hormonalnej lub kupujemy powodowani reklamową perswazją? Skoordynowana odmowa miłości czy konsumpcji nie wydaje się możliwym rozwiązaniem. Oznacza to najpewniej, że ujawnienie hipokryzji ma charakter systemowy i jest narzędziem utrzymywania latencji, podobnie jak dawniej karnawalizacja ${ }^{15}$. Tak jak w społeczeństwie zróżnicowanym warstwowo skarnawalizowane odwrócenie utrzymywało latencję w odniesieniu do zasady hierarchii, tak w społeczeństwie zróżnicowanym funkcjonalnie systemowe ujawnianie hipokryzji utrzymuje latencję w odniesieniu do funkcji. Oczywiście systemowa hipokryzja nie jest w żadnym razie tak wydolnym narzędziem ochrony latencji jak karnawalizacja, bowiem porządek warstwowy potrzebuje tak silnych semantyk jak Bóg czy Natura, by utrzymać system komunikacji w stabilnym horyzoncie czasowym. W społeczeństwie massmedialnie przyspieszonym horyzonty czasowe nie wymagają tak silnej ochrony, więc nacisk na ochronę latencji musi być odpowiednio mniejszy i bardziej elastyczny, co widać choćby po strukturalnych sukcesach gender. Systemowe ujawnienie hipokryzji działa więc ochronnie selektywnie, w odniesieniu do specyficznych struktur i funkcjonalizacji, do tych właśnie, które odpowiadają za dynamikę przyspieszenia. Innymi słowy latencja jest zaangażowana w kierunku ochrony dynamiki, nie zaś stabilności ${ }^{16}$. Odpowiedź na pytania o strukturalne warunkowanie konsumpcji będzie więc zbiegać się z odpowiedzią na pytanie o kierunki latencji.

15 Zob. W. Dudzik, Karnawały w kulturze, Warszawa 2005.

16 N. Luhmann, Systemy społeczne..., s. 314-323. 


\section{Medializacja gospodarki}

Przez konsumpcjonizm rozumieć będę semantyczny korelat, samoobserwacyjny artefakt uzyskiwania kompatybilności ze środowiskiem przez zmedializowaną gospodarkę. Nie próbuję tu konsumpcjonizmu ani psychologizować, ani umieszczać w kontekście politycznego panowania, ani, tym bardziej, uważać za wynik spisku wielkich korporacji. Interesuje mnie logika komunikacyjnego przejścia tradycyjnie ujmowanego jako przejście od społeczeństwa industrialnego do społeczeństwa konsumpcyjnego. Dokładnie to (obserwacyjne) przejście należy uznać za wynik procesu medializacji gospodarki. Samoreferencja gospodarki doprowadziła do stanu gospodarki nasyconej, która okazała się granicą wzrostu, granicą metaforycznej wyporności poza którą zaczynają się problemy z selekcją. Nie granicą procesu komodyfikacji, ale granicą irytacji środowiskowej. Wszystkiego jest za dużo, wszystko jest podobnej jakości i ma podobną cenę, pojawia się problem reprodukcji zasady konkurencji. Czym i jak konkurować, aby osiągnąć rezonans w środowisku? Baudrillard mylnie w tym miejscu zakłada, że jedyną i wystarczającą przesłanką jest samowytwarzająca się społeczna hierarchia, doświadczana jako nierówność nieustannie domagająca się kompensacji w formie konsumpcyjnego wyścigu. Sprawa jest o wiele bardziej skomplikowana i wymaga określenia form reorientacji gospodarki na czas przyszły. Dlaczego stabilizacja oznacza stagnację, skąd przymus zmiany, rozwoju i przymus nowości, i dzięki czemu są one osiagalne?

W gospodarce nasyconej uzyskanie oraz utrzymanie relewancji rynkowej jest równoznaczne $\mathrm{z}$ walką o uwagę i agregację uwagi. Uwaga jest elementarnym faktorem selekcji, ale w sytuacji nasycenia nie można już liczyć na samorzutną uwagę, należy ją pozyskiwać i to w sposób skoordynowany. Innymi słowy, należy próbować dyspersji. I nie wystarczy już pokrzykiwanie na bazarze. Gospodarka zdaje się na media. I to od razu w podwójnej roli: jako medialnie obserwowana, ciesząca się uwagą mediów, jak i narzucająca się do medialnej obserwacji, poszukująca uwagi. W wielkim uproszczeniu: początkowo bycie obserwowaną wywołuje reakcję w postaci raczej „defensywnego” public relations, zaś narzucanie się produkuje „ofensywną" reklamę. Zdanie się na media jest związane z dopasowaniem strukturalnym, z próbą sprostania typowo medialnym regułom selekcji, medialnej mechanice. Bycie znanym i zasada nowości to symbiotyczna forma, która wzmacnia orientację gospodarki na czas przyszły i wiąże ją z mediami masowymi. Produkty muszą być i znane, i nowe. Przyspieszenie gospodarki z czasów wyścigów cenowo-jakościowych dobrze zestraja się z przyspieszeniem medialnym. Ale nowość i „,znaność” nie mogą już opierać się na typowych sposobach wytwarzania przewagi rynkowej o charakterze kalkulacji jakościowo-cenowych, które są dokonaniem samej gospodarki. Teoremat dyspersji strukturalnej zakłada, że aby uzyskać medialną relewancję na poziomie karier strukturalnych (a tylko takie mogą zapewnić organizacjom gospodarczym odpowiednią porcję przyszłości), na- 
leży wziąć udział w medialnej socjodoksji, w produkcji ofert normalnościowych, w zmaganiach dyskursów. Innymi słowy organizacje gospodarcze potrzebują semantyk bogatszych od osiąganych wewnątrzsystemowo, legitymizować się czymś więcej niż tylko zyskiem lub stratą. Przy czym nowość i „,znaność” określają jedynie wstępne wymagania dopasowania strukturalnego; ,znaność” jest jedynie indykatorem medializacji, zaś nowość elementarną semantyką warunkującą. Ponadto ów mechanizm symbiotyczny wymusza presję przyszłościową w tym sensie, że czyni gospodarką przestarzałą, gdyż nowość pobudzająca produkcję „znaności” niesie ze sobą zalążek własnej klęski: powszechnie znana nowość przestaje być nowością i domaga się kolejnych nowości. Uwagę przyciąga bowiem to, co nowe. Ale sama semantyka nowości, choć czyni zadość warunkom sprzężenia mediów i gospodarki, jest semantyką zbyt jałową i płytką by zapewnić ofertom gospodarczym karierę strukturalną, może jedynie reprodukować uogólnione zainteresowanie. Oznacza to, że semantyki gospodarcze nie tylko nie mogą bazować jedynie na wewnątrzsystemowych osiągnięciach, lecz także nie mogą poprzestać tylko na spełnieniu wstępnych wymogów medializacji. Zamknięta samoreferencja gospodarki musi operować formami tematycznego otwarcia — otwiera się na tematy ekologiczne, polityczne czy medyczne. Nic w tym oczywiście nowego. Klasyczne analizy Webera mimo swej kontrowersyjności dobrze pokazują formy otwarcia gospodarki na tematy religijne, na religijne autowarunkowanie gospodarki ${ }^{17}$. Ale dostarczanie przez religię gospodarce stosownych semantyk utraciło już dawno wszelką dynamikę, wraz z funkcjonalną rekompozycją społeczeństwa. Skąd więc dziś gospodarka ma czerpać semantyki, które rozwiążą jej problemy selekcyjne i zapewnią środowiskowe dopasowanie? Aby realizować otwarcie semantyczne, trzeba obserwować. Ale gigantyczny wysiłek obserwacyjny gospodarki jest skierowany zasadniczo na nią samą. Obserwuje się ceny, stopy procentowe, wyceny ratingowe, wahania $\mathrm{PKB}$, bezrobocie, zmiany siły nabywczej, trendy konsumenckie, kursy giełdy i walut, poczynania konkurencji, koszty, inflację i tysiące innych czynników. Wszystkie te obserwacje podporządkowane są dopasowaniu gospodarki do samej siebie, do własnej dynamiki wytworzonej przez orientację na przyszłość: przyszłość wymusza planowanie z towarzyszącą mu hiperzłożonością, planowanie wysysa więc wszelkie moce obserwacyjne. Żadna organizacja gospodarcza nie jest $\mathrm{w}$ stanie efektywnie przeszukiwać otoczenia w poszukiwaniu odpowiednich semantyk, co oznaczałoby obserwację dyskursów. Można jednak zdać się na obserwację obserwacji dokonywaną w mass mediach lub przez nie, czyli zdać się na infradyskurs, orientować się na semantyki, które przeszły medialny probierz. Rzecz jasna przyszłościowa orientacja gospodarki, a także jej wewnętrzne rytmy nie pozwalają jej zatrzymać się na pianie newsów czy na prostych karierach tematycznych. I nie tylko dlatego, że nikt nie jest w stanie produkować tak szybko, również z tego powodu, że kariery tematyczne nie obiecują wystarczają-

${ }^{17}$ M. Weber, Etyka protestancka i duch kapitalizmu, przeł. D. Lachowska, Warszawa 2011. 
co stabilnej przyszłości, aby organizacje gospodarcze mogły się na nie sensownie zdać. Tylko infradyskursowe tematy, które osiągnęły status kariery strukturalnej lub wykazują odpowiednią potencję strukturalną, wróżącą przemianę w karierę strukturalną, mogą cieszyć się zainteresowaniem gospodarki. Łatwo to zauważyć choćby na przykładzie ekologii: dyskurs ekologiczny najpierw osiągnął medialną relewancję (między innymi dzięki działalności takich organizacji jak Greenpeace) i uzyskał ugruntowanie w karierach tematycznych (na przykład katastrofy ekologiczne: wyciek ropy z tankowca MT Exxon Valdez, katastrofa elektrowni w Czarnobylu), następnie przedostał się w obszar publicystyki, zgłaszając tym samym aspiracje do karier strukturalnych, i wszedł jako struktura do przestrzeni dyspersji; wylegitymizowana w ten sposób ekologia mogła stać się zasobem semantycznym dla gospodarki, prokurując „,przemysł” ekologiczny, ekologicznie zorientowane marki, ekologiczne trendy gospodarcze (na przykład ekologiczną energetykę, żywność, ubrania), „ekologiczne” komunikacje gospodarcze. Widoczna na powyższym przykładzie medializacja gospodarki nie ma charakteru „biernego" tematycznego otwarcia, lecz ma charakter strukturalnego sprzężenia: gospodarka przyczynia się do stabilizacji struktur „ekologicznych”, wspiera kariery i umożliwia akces środowiska, ugruntowuje struktury, na co media reagują wzmożoną wrażliwością ekologiczno-gospodarczą ${ }^{18}$. Na razie poprzestaniemy na wstępnej konstatacji, że medializacja gospodarki oznacza formę sprzężenia zwrotnego, w którym wzbogacane infradyskursowymi semantykami organizacje gospodarcze poddają się medialnej dyspersji. Struktury głębokie, warunkujące sprzężenie, należą do porządku latencji.

\section{Jednostka a konsumpcja}

Co podlega ochronie przez maskowanie motywów, blokowanie refleksji, podsuwanie prostych atrybucji? Nowoczesna mitologia ,ja”, dynamika indywidualizacji. Ona właśnie umożliwia powodzenie mariażu gospodarki i mediów, owocujące krytykowanymi, nieustannymi: nadkonsumpcją, „marnotrawstwem” oraz - paradoksalnie - depersonalizacją. Różnica między gospodarką łączącą się ze środowiskiem przez zaspokajanie potrzeb a gospodarką łączącą się przez konsumpcję — różnica ustabilizowana, podtrzymywana przez zgeneralizowane symboliczne media komunikacji — opiera się dziś na uwzględnieniu ,ja” w procesach komunikacyjnych. O ile bowiem zaspokajanie potrzeb wynikających z biologicznych właściwości gatunku jest warunkiem fizycznej reprodukcji środowiska, o tyle konsumpcja jest realizacją struktur komunikacyjnych (społecznych). Logika konsumpcyjnych pragnień nie jest tożsama z logiką potrzeb, nawet wtedy gdy

18 D. Lewiński, Snakeskin jacket. O medializacji gospodarki, „Dziennikarstwo i Media” 4, 2013, s. 17. 
pragnienie dotyczy zaspokajania potrzeb ${ }^{19}$. Nie ma powodu, by pragnienia nadmiernie humanizować i przypisywać ludziom, są one po prostu wyrazem struktur, oczekiwalności, co prawda (i co jest bardzo mylące) oczekiwalności względem i odnośnie do ,ja”. Innymi słowy konsumpcjonizm odpowiada za proces konstytucji, legitymizacji i nawiązywalności współczesnej, zindywidualizowanej jednostki. „Ja” jest do kupienia i staje się przez konsumpcję, przez konsumpcję jest też rozumiane i refleksyjne. Oczywiście nowoczesna mitologia ,ja” wszystkiemu zaprzeczy. Wolność i autonomia jednostki, tożsamość i osobowość, autentyczność i samorealizacja, bycie sobą, wyjątkowość, indywidualizacja itp., należą, wedle mitologicznych, upotocznionych wyobrażeń, do ontologii, są naturalnym stanem jednostki, a równocześnie potencją, której właśnie społeczeństwo, nie Bóg ani Natura, może stawiać tamy, dawać szanse i którą może zniekształcać. Ale nic tak nie napędza konsumpcjonizmu, jak chęć i obowiązek bycia sobą, przymus autoekspresji i indywidualizacji, a także — jednocześnie — chęć przynależności, uwspólnotowienia, co widać choćby w mechanizmie „,mody”. Konsumpcjonizm odgrywa dziś decydującą rolę w procesie, którym jest jednostka. I to zarówno w konfiguracji tożsamości-ja, jak i tożsamości-my (według terminologii Norberta Eliasa). Powstała na ten temat już obszerna literatura — która przeważnie zawodzi przez własne uwikłanie w nowoczesną mitologię ,ja”. Ale jeśli spróbujemy ująć nowoczesne ,ja” jako efekt mediatyzacji gospodarki, bez której nie mogłoby się ukonstytuować i rozwijać, uzyskujemy całkowicie odmienną optykę. Nie moglibyśmy bowiem rozważać indywidualności jednostki, jej tożsamości, potencjału samorealizacji czy wspólnotowej przynależności bez uwzględnienia wkładu konsumpcji w ich formowanie i stabilizację. Na poziomie semiologicznym jest to dobrze widoczne. Kiedy kupujemy kosmetyki, „ładne” ubrania, dodatki czy meble — konsumujemy piękno. Kiedy kupujemy naukową książkę, kurs dokształcający, ciekawą zagraniczną podróż — konsumujemy wiedzę i mądrość. Kiedy zaś kupujemy produkty wege/eko i wspieramy organizacje charytatywne — konsumujemy moralność. Odmowa jedzenia fast foodów, karnet na siłownię czy basen, suplementy diety — to przecież konsumpcja zdrowia. Kiedy zaś kupujemy dziecku wymarzoną zabawkę, partnerowi lub partnerce ulubioną potrawę czy płytę muzyczną wtedy konsumujemy miłość. Gdy zaś wybieramy na przykład „męskie” kosmetyki, odzież, jedzenie, filmy — to wtedy po prostu konsumujemy płeć kulturową. Jak wyglądałyby jednostka i społeczeństwo pozbawione takich konsumpcyjnych struktur? Czy w ogóle można byłoby mówić o indywidualizacji, tożsamości, samorealizacji i tym podobnych — i co miałyby one wtedy oznaczać?

19 Jeśli potrzebuję okrycia przed chłodem, mógłbym kupić byle co, o ile spełniałoby termoizolacyjne warunki — nikt tak jednak raczej nie czyni, okrycie musi spełniać specyficzne, semantyczne warunki. 


\section{Bibliografia}

Aldridge A., Konsumpcja, przeł. M. Żakowski, Warszawa 2006.

Appadurai A., Nowoczesność bez granic. Kulturowe wymiary globalizacji, przeł. Z. Pucek, Kraków 2005.

Baudrillard J., Społeczeństwo konsumpcyjne - jego mity i struktury, przeł. S. Królak, Warszawa 2006.

Bauman Z., Konsumowanie życia, przeł. M. Wyrwas-Wiśniewska, Kraków 2009.

Bourdieu P., Dystynkcja. Społeczna krytyka władzy sądzenia, przeł. P. Biłos, Warszawa 2005.

Bourdieu P., Medytacje pascaliańskie, przeł. K. Wakar, Warszawa 2006.

Dudzik W., Karnawaty w kulturze, Warszawa 2005.

Elias N., Społeczeństwo jednostek, przeł. J. Stawiński, Warszawa 2008.

Gergen K., Nasycone Ja. Dylematy tożsamości w życiu współczesnym, przeł. M. Marody, Warszawa 2009.

Iwasiński Ł., Socjologiczne dyskursy o konsumpcji, Gdańsk 2016.

Jacyno M., Kultura indywidualizmu, Warszawa 2007.

Kaczmarczyk M., Wstęp do socjologicznej teorii własności, Warszawa 2006.

Kaufmann J.C., Ego. Socjologia jednostki, przeł. K. Wakar, Warszawa 2004.

Lewiński D., Snakeskin jacket. O medializacji gospodarki, „Dziennikarstwo i Media” 4, 2013.

Luhmann N., Realność mediów masowych, przeł. J. Barbacka, Wrocław 2009.

Luhmann N., Systemy społeczne. Zarys ogólnej teorii, przeł. M. Kaczmarczyk, Kraków 2007.

Marody M., Jednostka po nowoczesności. Perspektywa socjologiczna, Warszawa 2015.

Miller D., Teoria zakupów, przeł. M. Król, Kraków 2011.

Ogilvy D., Wyznania człowieka reklamy, przeł. W. Madej, Warszawa 2000.

Simmel G., Filozofia pieniądza, przeł. A. Przyłębski, Warszawa 2012.

Strzyczkowski K., Tożsamość w kontekście tendencji rozwojowych społeczeństwa ponowoczesnego, Warszawa 2012.

Tittenbrun J., Gospodarka w społeczeństwie. Zarys socjologii gospodarki i socjologii ekonomicznej w ujęciu strukturalizmu socjoekonomicznego, Poznań 2012.

Veblen T., Teoria klasy próżniaczej, przeł. J. i K. Zagórscy, Warszawa 2008.

Vogl J., Widmo kapitału, przeł. K. Sosnowska, Warszawa 2015.

Weber M., Etyka protestancka i duch kapitalizmu, przeł. D. Lachowska, Warszawa 2011. 